University of Miami Law School Institutional Repository

University of Miami National Security \& Armed Conflict Law Review

$7-1-2015$

\title{
Fair and Impartial? Military Jurisdiction and the Decision to Seek the Death Penalty
}

Clark Smith

Follow this and additional works at: http://repository.law.miami.edu/umnsac

Part of the Military, War and Peace Commons, and the National Security Commons

\section{Recommended Citation}

Clark Smith, Fair and Impartial? Military Jurisdiction and the Decision to Seek the Death Penalty, 5 U. Miami Nat'1 Security \& Armed Conflict L. Rev. 1 (2015)

Available at: http://repository.law.miami.edu/umnsac/vol5/iss2/4

This Article is brought to you for free and open access by Institutional Repository. It has been accepted for inclusion in University of Miami National Security \& Armed Conflict Law Review by an authorized administrator of Institutional Repository. For more information, please contact library@law.miami.edu. 


\title{
Fair and Impartial? Military Jurisdiction and the Decision to Seek the Death Penalty
}

\author{
Clark Smith $^{*}$
}

"When the punishment may be death, there are particular reasons to ensure that the men and women of the Armed Forces do not by reason of serving their country receive less protection than the Constitution provides for civilians. "I

- John Paul Stevens

\section{Table of Contents}

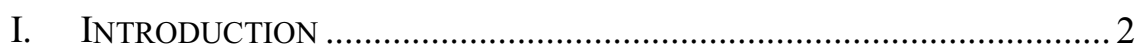

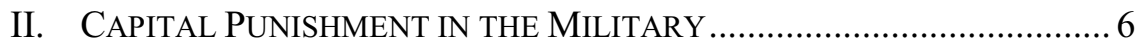

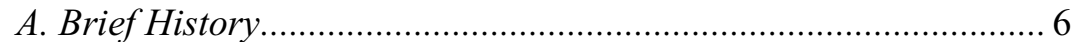

B. Military and Civilian Justice Systems-Similar, but Different ..... 8

C. "Recent" Military Executions...................................................... 11

III. ARbitrary Nature of the Decision to SEeK the DeAth

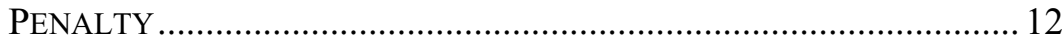

A. The Military's Decentralized System of Justice ........................... 12

B. Inconsistent Application of Justice - A Contrast in Crimes ........ 13

1. The My Lai and Kandahar Massacres of Non-

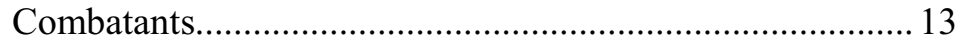

2. Capital Referral Based on the Crime, or Not......................... 16

C. When the Victims are Service Members...................................... 18

1. Seeking Capital Punishment for Killing Our Own-In

Peace.....

The author, a retired military officer and current Adjunct Professor of International Relations at Webster University's Washington, DC metropolitan-area campus, wishes to acknowledge the insightful edits and constructive comments provided by Professor John D. Bessler, Adjunct Professor of Law at Georgetown University Law Center and Lieutenant Commander Rich Federico, JAG Corps, U.S. Navy.

1 Loving v. United States, 517 U.S. 748, 774 (1996) (Stevens, J., concurring). 
2. Seeking Capital Punishment for Killing our Own-In

War.

IV. ABUSE OF THE DUAL SOVEREIGNTY DOCTRINE

A. When Can, and Should, the Military Exercise Jurisdiction? ...... 21

1. The Competing Views of O'Callahan and Solorio ............... 22

2. O'Callahan Overruled by Solorio_-Actual Implications....... 23

B. When the State Secures a Conviction..................................... 23

C. When the State Fails to Secure a Conviction ............................. 24

D. When the Service Member is Acquitted by the State.................. 26

V. ELIMINATION OF MILITARY JURISDICTION OVER CAPITAL

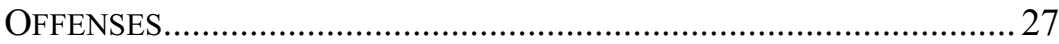

A. Rationale for Jurisdiction Over Capital Crimes Obsolete......... 27

B. Article III and State Courts More Than Capable....................... 28

C. Jurisdictional Manipulation Unfair to Service Members ........... 29

VI. CONCLUSION............................................................................ 31

\section{INTRODUCTION}

On Mother's Day in 1985, the Cumberland County Sheriff's Department discovered the bodies of a young woman and two of her daughters in Fayetteville, North Carolina. Katie Eastburn had been raped and stabbed multiple times. Her daughters, ages three and five, had also been stabbed multiple times. Found in her crib, unharmed, was Katie Eastburn's youngest daughter, twenty-one-month-old Jana. ${ }^{2}$ News of the murders rocked the military town, home to another infamous murder in which a Special Forces surgeon was convicted only six years earlier of killing his family. ${ }^{3}$

At the time of the murders, Katie's husband Gary, an officer in the U.S. Air Force, had been away attending a professional development course near Montgomery, Alabama. Upon his return, he provided investigators with information about a man who had stopped by the house on the previous Tuesday to discuss adopting the Eastburns' dog ahead of their upcoming move to the United Kingdom. That man, a soldier from nearby Fort Bragg by the name of Timothy Hennis, went to see investigators after he and his wife saw news reports requesting information about a man who had picked up the Eastburns' dog. Hennis

2 See Nicholas Schmidle, Three Trials for Murder, THE New Yorker, Nov. 14, 2011, at 56,58 .

$3 \quad I d$. at 59 . 
was subsequently picked out of a photo array and arrested shortly thereafter.

Though there was significant physical evidence, technology at that time prevented it from being conclusively linked to Hennis. Nonetheless, Hennis was found guilty a year later on three counts of first-degree murder and one count of rape following a trial in which jurors were shown dozens of graphic photos of the bloody crime scene. ${ }^{4}$ Hennis was subsequently sentenced to death. ${ }^{5}$ Attorneys for Hennis began preparing his appeal as Hennis was transferred to North Carolina Central Prison's death row. In 1988, the North Carolina Supreme Court awarded Hennis a new trial, holding that the admission of autopsy photos, which added little to crime scene photographs, constituted reversible error given their gruesome content, their over-publication to the jury, and the lack of overwhelming evidence of defendant's guilt. ${ }^{6}$ The following year, nearly four years after the murders, a second trial acquitted Hennis of the murders and rape. ${ }^{7}$

Hennis departed the courtroom that day, after spending considerable time on death row, a free man. And no one imagined that he would ever be returned to death row; however, the Army officials, not yet even involved in the case, would seek jurisdiction under military law, some twenty years later.

The decision to seek and carry out the death penalty is not one to be taken lightly. In choosing to deprive one of life in the name of justice, the government must closely scrutinize the process to ensure the condemned has been afforded all necessary protections. ${ }^{8}$ And the military, despite its imposition of a higher standard of conduct both professionally and personally, should be no different. The Supreme Court of the United States has noted that military law is "a rough form of justice emphasizing summary procedures, speedy convictions and stern penalties with a view to maintaining obedience and fighting fitness in the ranks." In addressing the military's ultimate punishment, however, the Court has also noted that "when the punishment may be death, there are particular reasons to ensure that the men and women of the Armed Forces do not by reason of serving their country receive less protection than the

See State v. Hennis, 372 S.E.2d 523, 528 (N.C. 1988).

See Schmidle, supra note 2, at 60.

See Hennis, 372 S.E.2d at 528.

See Schmidle, supra note 2, at 62.

See Powell v. Alabama, 287 U.S. 45, 71-74 (1932) (highlighting the unique nature of offenses in which the death penalty may be imposed by holding that court's failure to make effective appointment of counsel to assist defendants in a capital trial was a denial of due process of law).

$9 \quad$ Reid v. Covert, 354 U.S. 1, 35-36 (1957); see also United States v. Denedo, 556 U.S. 904, 918 (2009). 
Constitution provides for civilians." ${ }^{10}$ But being afforded less protection is precisely the effect, even if indirectly, when senior military commanders employ non-objective criteria and manipulate jurisdictional control in determining to punish capital offenses.

This paper argues that the military does not exercise jurisdiction in a fair and impartial manner over capital offenses not directly connected to the role of the armed services. The purpose of the military justice system is the maintenance of good order and discipline in the armed services. ${ }^{11}$ And, arguably, the military was better positioned long ago to administer justice over capital offenses, including those even remotely connected to the military's role. For example, Thomas Jefferson considered executions necessary to maintain the order and discipline of Continental Army soldiers and even advocated expanding the number of death-eligible offenses during the Revolutionary War. ${ }^{12}$ But the more recent evolution from a fixed, forward-deployed force to a transformed, mostly U.S.based expeditionary force, coupled with advancements in global communications and transportation technology, diminish the necessity for the military justice system in its contemporary structure. The current system, dating several generations, was established to maintain order and discipline in a manner to which a civilian justice system could not readily and efficiently respond. The aim of this paper is to promote advocacy for the removal from the military's jurisdiction of capital offenses not directly connected to the role of the military. ${ }^{13}$

The paper is divided into four parts. Part I provides a summary of the history of the military death penalty and aspects unique to military justice. Although similarly aligned to civilian justice systems, ${ }^{14}$ the military's system differs in several ways, such as who decides to seek the death penalty and the number of protections afforded the condemned following conviction.

Part II then examines the arbitrary nature of the decision by senior officers with authority to seek the death penalty as well as the resulting inconsistent outcomes. Though a highly structured society with strong

\footnotetext{
10 Loving v. United States, 517 U.S. 748, 774 (1996) (Stevens, J., concurring).

11 See Manual for Courts-Martial, United States pt. 1, para. 3 (2012 ed.).

12 See John D. Bessler, Cruel \& Unusual: The american DeATH Penalty and the FOUNDERS' EIGHTH AMENDMENT 146 (Northeastern Univ. Press 2012).

13 See Lieutenant Commander Rich Federico, The Unusual Punishment: A Call for Congress to Abolish the Death Penalty Under the Uniform Code of Military Justice for Unique Military, Non-Homicide Offenses, 18 Berkeley J. CRIM. L. 1 (2013) (advocating for abolishment of the military death penalty for the unique military, non-homicide offenses).

14 Rod Powers, Military Justice 101 - Part VII, USMILITARY.ABOUT.COM, http:// usmilitary.about.com/od/justicelawlegislation/l/aacmartial2.htm (last visited July 6, 2013).
} 
adherence to the chain of command, the military justice system is very much decentralized in disposing of violations of military law, including offenses not specific to the role of the military. ${ }^{15}$ With no standing courts or sentencing guidelines, ${ }^{16}$ two service members accused of similar crimes may experience dramatically inconsistent judicial outcomes. Part II will also analyze several cases in which senior commanders did and did not initially seek the death penalty, including cases in which the death penalty was pursued through adjudication.

Part III of the paper will look at the military's authority to exercise jurisdiction, both in situations where civilian authorities ceded jurisdiction at the military's request and where the military exercised jurisdiction successively to that already exercised by civilian authorities. Though not a violation of the prohibition on double jeopardy, ${ }^{17}$ the military's manipulation of separate sovereigns to facilitate maximum effort in obtaining a conviction in capital and other serious offenses calls into question whether service members, by virtue of their service, are afforded the same constitutional and legal protections as civilians. ${ }^{18}$ Part III will also analyze several cases tried successively in different sovereigns in the effort to ensure conviction by court-martial should state efforts fail.

Finally, Part IV will advocate for the removal of the military's authority to exercise jurisdiction over capital offenses with no direct nexus to the armed services. The justification for the military having its own justice system authorizing capital punishment is hardly still valid as a result of advancements in technology and the professionalization of arms. Eliminating the military's jurisdiction over capital offenses can easily cure the perception of the arbitrary nature of the application of military justice in capital cases. The civilian justice system has long proved to have the capacity to address such offenses committed by those otherwise subject to military justice. The lack of fairness and impartiality demonstrated by the military's manipulation of successive sovereigns can also be cured by transferring jurisdiction over capital cases to the respective Article III and state courts.

See Federico, supra note 13, at 5.

See Powers, supra note 14.

United States v. Lanza, 260 U.S. 377, 385 (1922) (holding that an act which was made an offense both by a state prohibition law and by a federal legislative act is an offense against each sovereignty punishable by each without violating the Fifth Amendment prohibition on double jeopardy).

18 Major Charles L. Pritchard, Jr., The Pit and the Pendulum: Why the Military Must Change Its Policy Regarding Successive State-Military Prosecutions, ARMY LaW, Nov. 2007, at 1 . 
The paper concludes by revisiting the main points, briefly commenting further upon the impact of the growing profession of arms, and relooking the rationale of the Court's decision in O'Callahan $v$. Parker, ${ }^{19}$ all in the context of justifying the elimination of the military's authority to exercise jurisdiction over capital offenses.

\section{CAPITAL PUNishment IN THE MiLitARY}

\section{A. Brief History}

American military courts-martial have always had the authority to impose the death penalty, though not always for capital murder committed within the U.S. during peacetime. The Articles of War, established by the Second Continental Congress in 1775, fixed courtmartial powers and restricted their jurisdiction over capital offenses. Capital punishment was authorized for fourteen military offenses but precluded jurisdiction over ordinary capital crimes that were punishable by the law of the land and were not specifically military offenses. ${ }^{20}$ In 1863 , Congress, concerned about the inability of civil courts to function in all places during hostilities, granted authority to the military to impose the death penalty over common law capital crimes committed during wartime. ${ }^{21}$ In 1916, Congress further granted a general jurisdiction to the military over common law felonies committed by service members, excepting murder and rape committed within the U.S. during peacetime. $^{22}$ Jurisdiction of murder or rape so committed during peacetime was given to civilian authorities. However, even this restriction was lifted in 1950 with the establishment of the Uniform Code of Military Justice (UCMJ) by Congress. ${ }^{23}$ Article 118 of the UCMJ describes the four types of murder subject to the jurisdiction of a courtmartial: any person subject to this chapter who, without justification or excuse, unlawfully kills a human being, when he (1) has a premeditated design to kill; (2) intends to kill or inflict great bodily harm; (3) is

19 O'Callahan v. Parker, 395 U.S. 258 passim (1969), overruled by Solorio v. United States, 483 U.S. 435, 436 (1987).

$20 \quad$ See Loving v. United States, 517 U.S. 748, $752-54$ (1996).

21 Id. at 753 (citing Act of Mar. 3, 1863, § 30, 12 Stat. 736, Rev. Stat. $\S 1342$, Art. 58 (1875); Coleman v. Tennessee, 97 U.S. 509, 514 (1879)).

${ }^{22}$ Id. (citing Articles of War of 1916, ch. 418, § 3, Arts. 92-93, 39 Stat. 664).

23 "Following World War II, Congress, in an attempt to reform and modernize the system of military law," enacted the UCMJ, 10 U.S.C. $\S 801$ et seq., in 1950, setting forth "governing principles for military courts. The UCMJ as a whole establishes an intricate system of military justice." See Parisi v. Davidson, 405 U.S. 34, 41 (1972) (internal citations omitted); Hamdan v. Rumsfeld, 548 U.S. 557, 638-39 (2006). 
engaged in an act which is inherently dangerous to another and evinces a wanton disregard of human life; or (4) is engaged in the perpetration or attempted perpetration of burglary, sodomy, rape, rape of a child, sexual assault, sexual assault of a child, aggravated sexual contact, sexual abuse of a child, robbery, or aggravated arson; is guilty of murder, and shall suffer such punishment as a court-martial may direct, except that if found guilty under clause (1) or (4), he shall suffer death or imprisonment for life as a court-martial may direct. ${ }^{24}$

In 1983, the U.S. Court of Military Appeals (CMA) ${ }^{25}$ addressed the constitutionality of military capital punishment in light of the Supreme Court's decision in Furman v. Georgia. ${ }^{26}$ Despite finding valid most of the procedures required by the military's death penalty process, the CMA found one fundamental defect - the lack of the requirement of the courtmartial panel members to "specifically identify the aggravating factors upon which they have relied in choosing to impose the death penalty.",27 The constitutional defect identified in United States v. Matthews ${ }^{28}$ was cured in 1984 with an Executive Order ${ }^{29}$ promulgating the Rule for Courts-Martial (RCM) 1004. ${ }^{30}$ The rule, as amended, requires a unanimous finding that the accused was guilty of a capital offense before a death sentence could be imposed, ${ }^{31}$ presence of at least one aggravating factor, and any extenuating or mitigating circumstances be substantially outweighed by any admissible aggravating circumstances. ${ }^{32}$ RCM 1004 enumerates eleven categories of aggravating factors sufficient for

\footnotetext{
24 UCMJ, art. 118, 10 U.S.C. $\$ 918$ (2012).

25 The U.S. Court of Military Appeals [hereinafter CMA] is an Article I court that exercises worldwide appellate jurisdiction over persons subject to the UCMJ and reviews decisions from the intermediate appellate courts of each of the armed services; it was redesignated the U.S. Court of Appeals for the Armed Forces [hereinafter CAAF] by Congress in 1994. See Ryder v. United States, 515 U.S. 177, 179 n.1 (1995) ("The National Defense Authorization Act for Fiscal Year 1995 . . changed the nomenclature for the military appellate courts. The previous 'Court[s] of Military Review' were rechristened as the 'Court[s \} of Criminal Appeals' and the previous 'United States Court of Military Appeals' was redesignated as the 'Untied States Court of Appeals for the Armed Forces.", (internal citation omitted)).

26 Furman v. Georgia, 408 U.S. 238 passim (1972) (finding capital punishment unconstitutional and instituting a de facto moratorium in the United States).

$27 \quad$ United States v. Matthews, 16 M.J. 354, 379 (C.M.A. 1983).

28 See id. ("Article 118(1) of the Code, which proscribes premeditated murder, "parallels numerous statutes struck down in Furman and its companions." (quoting United States v. Gay, 16 M.J. 586, 597 (A.F.C.M.R. 1983) aff'd, (C.M.A. Apr. 19, 1984)).

29 See Exec. Order No. 12,460, 49 Fed. Reg. 3169 (Jan. 26, 1984).

$30 \quad$ See generally R. CTS-MARTIAL 1004.

31 See R. Cts-Martial 1004(a)(2); accord 10 U.S.C. $\S$ 852(a)(1)).

32 See R. CTS-Martial1004(b).
} 
imposition of the death penalty. ${ }^{33}$ It also provides that the accused have "broad latitude to present evidence in extenuation and mitigation," ${ }^{34}$ and are entitled to have the court-martial panel members instructed to consider all such evidence before deciding upon a death sentence. ${ }^{35}$

After modification to comport with Gregg v. Georgia, ${ }^{36}$ the next significant change to the military's capital punishment process was the legislative modification to the panel size. Prior to the National Defense Authorization Act (NDAA) for Fiscal Year 2002, a court-martial panel sitting for a capital case could number as few as five members. ${ }^{37}$ Following the amendment, however, the minimum number of panel members required to sit for a case in which the accused could be sentenced to death increased to twelve, and can only be less if some military exigency exists. ${ }^{38}$ Thus, today, two of the six condemned inmates currently on military death row were sentenced prior to the statutory requirement for twelve-member panels. ${ }^{39}$

\section{B. Military and Civilian Justice Systems-Similar, but Different}

Unlike most civilian prosecutors weighing whether to seek the death penalty for a capital offense, military prosecutors are not influenced by peripheral matters such as reelection or being labeled "soft on crime." In fact, military prosecutors do not even have decision-making authority in the charging-decision process. The decision to seek the death penalty rests with the General Court-Martial Convening Authority, more commonly referred to as simply the convening authority (CA). ${ }^{40}$ Generally, the CA for a general court-martial is a senior commander in the accused's chain of command. A general court-martial is but one of three types of courts-martial and reserved for the most serious offenses under the UCMJ. The attorney responsible for advising and carrying out the CA's directives is known in military parlance as the Command or

See R. Cts-Martial 1004(c).

See R. CTS-MARTIAL1004(b)(3).

See R. CtS-MARTIAL 1004(b)(6).

Gregg v. Georgia, 428 U.S. 153 (1976). This decision reaffirmed acceptance of the use of the death penalty by setting forth the capital sentencing procedures that must be employed to comport with the Eighth Amendment ban on cruel and unusual punishments. 37 See Jonathan Choa, Civilians, Service-Members, and the Death Penalty: The Failure of Article 25a to Require Twelve-Member Panels in Capital Trials for Non-Military Crimes, 70 Fordham L. Rev. 2065, 2065 (2002).

$38 I d$. (citing the text of Article 25a that was added the UCMJ in the NDAA for Fiscal Year 2002).

39 Description of Cases for Those Sentenced to Death in U.S. Military, DEATH PENALTY INFORMATION CENTER, http://www.deathpenaltyinfo.org//description-casesthose-sentenced-death-us-military-0 (last visited Feb. 17, 2015).

$40 \quad$ See R. Cts-Martial 1004(b)(1)(A). 
Staff Judge Advocate (SJA). The SJA, who is the CA's principle legal advisor, will make a recommendation as to whether the death penalty should be sought, but that decision ultimately rests with the CA. Until a 2005 amendment to the Manual for Courts-Martial (MCM), ${ }^{41}$ a capital offense at a general court-martial was referred capitally unless referred expressly precluding the death penalty. ${ }^{42}$ Now, a case is referred noncapitally unless the CA specifically intends to have the case tried capitally. Unique to military justice is that the CA appoints the pool of those from which the panel members, finally seated through the voir dire process, are selected. ${ }^{43}$ Unlike courts-martial in which the death penalty is not sought, capitally-referred charges require that the defendant be precluded from pleading guilty, ${ }^{44}$ that he be tried before a panel, ${ }^{45}$ and that the panel's findings be unanimous, both on the issue of guilt and for the imposition of a death sentence. ${ }^{46}$ Another unique aspect is that should the accused be convicted at court-martial of certain non-qualifying offenses, the CA must approve the findings and in so doing, may arbitrarily vacate the conviction or reduce the sentence imposed by the military judge or panel. ${ }^{47}$

The military's application of the capital punishment process affords those condemned to death greater protections in some areas, though still less in others. Somewhat unique to the military's appellate process is that it provides two levels of mandatory appeals for death sentences, one of only two jurisdictions in the U.S. to do so. ${ }^{48}$ In the military, intermediate appellate courts have compulsory jurisdiction over death penalty cases. ${ }^{49}$ The services' intermediate courts of appeal broadly review sentence

41 The Manual for Courts-Martial guides the conduct of courts-martial; part II of the Manual for Courts-Martial explains the Rules for Courts-Martial.

$42 \quad$ See Exec. Order No. 13,387, 3 C.F.R. 178 (2006), reprinted as amended 10 U.S.C. $\S \S$ 801-946. (This order amended R. CTS-Martial 103(2) and R. Cts-Martial 201(f)(1)(A)(iii)(b)); the "referral of charges" is the convening authority action directing that a case be tried by court-martial); see also R. CTS-MARTIAL 601(a) (describing what is a referral for charges of accused to be tried by court-martial).

43 See Dwight Sullivan, A Matter of Life and Death: Examining the Military Death Penalty's Fairness, 45-Jun FED. LAw 38, 41 (Jun. 1998),

44 See R. Cts-Martial 910(a)(1).

45 See R. Cts-Martial 201(f)(1)(C).

46 See R. Cts-Martial 1004(a)(2) and 1006(d)(4)(A).

47 Prior to 2014 , this authority was unqualified but has since been significantly diminished. See R. Cts-MarTial 1107(c); UCMJ art. 60, 10 U.S.C. $\S 860$ (2012); National Defense Authorization Act for Fiscal Year 2014 [hereinafter NDAA FY14], Pub. L. No. 113-66, § 1702 (2013); National Defense Authorization Act for Fiscal Year 2015 [hereinafter NDAA FY15], Pub. L. No. 113-291, § 531 (2014).

48 The other is Tennessee. See generally Lee Davis \& Bryan Hoss, Tennessee's Death Penalty: An Overview of Procedural Safeguards, 31 U. MEM. L. Rev. 779, 799-800 (2001); see also UCMJ art. 66, 10 U.S.C. § 866 (2012).

49 UCMJ art. 66(b), 10 U.S.C. $\S 866(b)$ (2012). 
appropriateness and also both the evidence's legal as well as its factual sufficiency. ${ }^{50}$ While the former is not atypical, the latter is. ${ }^{51}$ Additionally, Congress requires that the U.S. Court of Appeals for the Armed Forces ("CAAF") review every case in which a service's intermediate appellate court upholds death as the sentence. ${ }^{52}$ Following the CAAF's ruling, the condemned may then appeal to the U.S. Supreme Court. After the Supreme Court either denies certiorari or affirms the CAAF ruling in a military capital case, it is then forwarded for review by the executive branch. ${ }^{53}$ The President must expressly approve the death sentence. ${ }^{54}$ And if the President so approves, the condemned may then pursue habeas relief in the Article III judiciary. ${ }^{55}$

Of the six men currently on military death row at the U.S. Disciplinary Barracks (USDB) at Fort Leavenworth, Kansas, only one, Ronald Gray, has a sentence approved by the President. Gray, however, was granted a stay on November 26, 2008, fourteen days before his execution was to be carried out, so that his attorneys could file a habeas corpus petition. ${ }^{56}$ Gray's petition was the first since $1961,{ }^{57}$ prior to the adoption of federal statutes now governing habeas review of death sentences of civilians ${ }^{58}$ According to Dwight Sullivan, a senior military reserve and former ACLU attorney who has written extensively on the military's death penalty, "[t]he scope of Article III courts' review of military justice cases determines whether the writ of habeas corpus will provide meaningful protection for condemned service members' constitutional rights." 59

In stressing the lack of meaningful habeas review, Sullivan explains that "because military death row is located in Kansas, federal habeas cases will be litigated under the Tenth Circuit's precedent. The Tenth Circuit bars habeas relief for claims that were 'fully and fairly considered' by a military court — even if the military court denied the

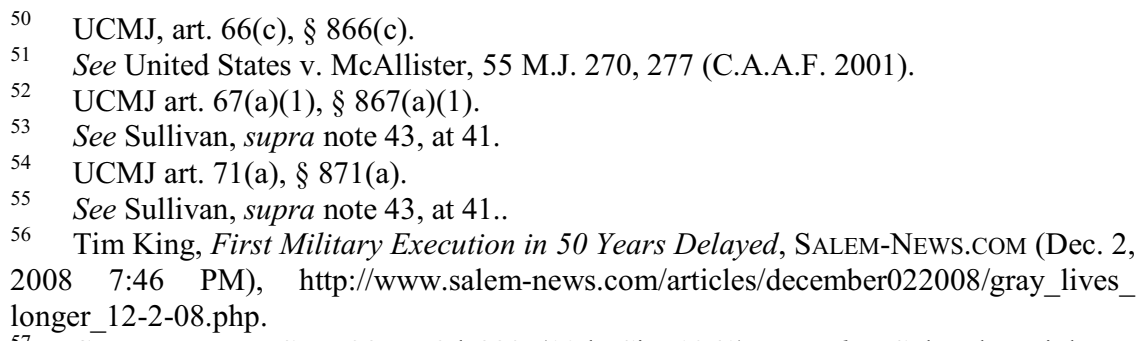

See Bennett v. Cox, 287 F.2d 883 (10th Cir. 1961); see also Colonel Dwight H. Sullivan, USMCR, Killing Time: Two Decades of Military Capital Litigation, 189 MiL. L. REV. 1, 29-30 (2006).

58 See Sullivan, supra note 43, at 29-30.

59 Captain Dwight H. Sullivan, The Last Line of Defense: Federal Habeas Review of Military Death Penalty Cases, 144 MiL. L. REv. 1, 11-13 (1994). 
claim without explanation. ${ }^{60}$ Claims that are not presented before the military courts, on the other hand, are generally held to be waived. Thus, the Tenth Circuit's case law establishes a Catch-22 that virtually precludes habeas relief for military petitioners." ${ }^{61}$

Whether the protections afforded the condemned on death row are sufficient will remain debatable for as long as the death sentence remains a sentencing option. And though still an option for capitally-referred offenses, of which several are considered purely military capital offenses $^{62}$ unlike murder, ${ }^{63}$ the fact is that the death penalty is seldom carried out. ${ }^{64}$

\section{C. "Recent" Military Executions}

Since the reintroduction of the military death penalty in $1984,{ }^{65}$ no death sentence by the military has been carried out, and eleven of sixteen death sentences have been overturned. ${ }^{66}$ In fact, the last military execution carried out was in 1961 and for an offense other than murder. John Bennett, a black soldier stationed in Europe, was hanged at Fort Leavenworth for the rape and attempted murder of an eleven-year-old white Austrian girl. Ironically, Austria did not have the death penalty and, prior to Bennett's hanging, the girl's parents unsuccessfully petitioned President Kennedy to spare Bennett's life. ${ }^{67}$

The last military execution for a purely military offense was carried out on January 31, 1945 in France. Edward Slovik was executed by an eleven-man firing squad following conviction at court-martial for the

60 Id. at 16-22; see also Lips v. Commandant, 997 F.2d 808, 812 (10th Cir. 1993), cert. denied, 510 U.S. 1091 (1994).

61 Sullivan, supra note 43, at 22.

62 UCMJ art. 94, 10 U.S.C. § 894 (2012) (mutiny); UCMJ art. 99, 10 U.S.C. § 899 (2012) (misbehavior before the enemy); UCMJ art. 100, 10 U.S.C. $\S 900$ (2012) (subordinate compelling surrender); UCMJ art. 102, 10 U.S.C. § 902 (2012) (forcing a safeguard); UCMJ art. 104, 10 U.S.C. § 904 (2012) (aiding the enemy); UCMJ art. 106a, 10 U.S.C. $\S 906 a(2012)$ (espionage).

63 UCMJ art. 118, 10 U.S.C. § 918 (2012).

64 See Federico, supra note 13, at 18-25.

65 See Exec. Order No. 12,460, 49 Fed. Reg. 3169 (1969), reprinted as amended in 10 U.S.C. $\S 47$ (1984).

${ }_{66}$ U.S. MILITARY: Latest Sentence Reversal Follows Trend of Rarely Using Death Penalty, Death Penalty Information Center, http://www.deathpenaltyinfo.org/usmilitary-latest-sentence-reversal-follows-trend-rarely-using-death-penalty (last visited Feb. 17, 2015).

67 See generally Lieutenant Commander Stephen C. Reyes, Dusty Gallows: The Execution of Private Bennett and the Modern Capital Court-Martial, 62 NAVAL L. Rev. 103 (2013); Richard A. Serrano, Last Soldier to Die at Leavenworth Hanged in an April Storm, Los ANGeles Times (July 12, 1994), http://articles.latimes.com/1994-0712/news/mn-14826_1_black-soldier. 
sole offense of desertion after he abandoned his unit during their advance through France. ${ }^{68}$ Following his desertion and subsequent opportunity to rejoin his unit, he indicated that if he returned to the front lines he would desert again. So that further desertions might be deterred, he became the first person since the Civil War to be punished for that crime. ${ }^{69}$ Slovik was just twenty-four-years-old at the time of his execution. Coincidentally, Dwight Eisenhower had a hand in the executions of both Slovik and Bennett. Prior to the UCMJ and under the Articles of War, ${ }^{70}$ General Eisenhower, as Commander of the European Theater, confirmed Slovik's death sentence. ${ }^{71}$ After the establishment of the UCMJ by Congress in $1950,{ }^{72}$ President Eisenhower approved the death sentence of Bennett. ${ }^{73}$

\section{Arbitrary Nature of the Decision to Seek the Death PENALTY}

\section{A. The Military's Decentralized System of Justice}

Charging decisions in the military are part of a decentralized process. Therefore, those decisions can, and do, lead to substantially inconsistent outcomes. Capital and other serious offenses referred to a general courtmartial are done so at the sole discretion of the $\mathrm{CA},{ }^{74}$ though more likely than not with the advice of the SJA. The result of this decentralization is that two service members who commit crimes very similar, if not identical, to one another, may be dealt with in entirely different manners for reasons having nothing to do with the offense. For example, one's situation may result in referral to court-martial while the other's may be disposed of non-judicially, ${ }^{75}$ or even administratively for less serious

68 Benedict B. Kimmelman, The Example Of Private Slovik, AmERICAN Heritage, Sept.-Oct. 1987, available at http://www.americanheritage.com/node/55767.

69 See 1945: Private Eddie Slovik, the Last American Shot for Desertion, EXECUTEDTODAY.COM (Jan. 31, 2009), http://www.executedtoday.com/2009/01/31/1945private-eddie-slovik-desertion/ (last visited April 10, 2015).

$70 \quad$ See generally Revision of the Articles of War 1912-1920: Hearing on S.64 Before the S. Subcomm. of Comm. on Military Affairs, 66th Cong. (1920); see also H.R. REP. No. 66-940 (1920).

71 See Kimmelman, supra note 68 , at 3.

72 See Uniform Code of Military Justice, Pub. L. No. 81-506, ch. 169, 64 Stat. 107 (1950) (codified at 10 U.S.C. $\S \S 801-946$ (2012)). The UCMJ is the foundation of U.S. military law.

73 See Reyes, supra note 67, at 109.

74 See R. CTS-Martial 601(a) (the "referral of charges" is the convening authority action directing a case to be tried by court-martial).

75 See UCMJ art. 15, 10 U.S.C. $\$ 815$ (2012). 
offenses. $^{76}$ Many factors lead to such a disparity, including the recommendation of a service member's chain of command, or even the individual discretion of the CA. It is, however, difficult to imagine the referral of a capital case, by a $\mathrm{CA}$, absent consultations with the particular service's most senior legal advisers and senior civilian and uniformed leaders. Further, it is likely that the executive branch's senior military and legal advisors are consulted as well, depending on the nature of the case. With that said, the decision still lies, technically, with the CA. ${ }^{77}$ While one CA may seek the death penalty for a heinous crime, another CA may not.

\section{B. Inconsistent Application of Justice-A Contrast in Crimes}

\section{The My Lai and Kandahar Massacres of Non-Combatants}

At the height of the Vietnam War, a very unpopular war, well over five hundred civilians, including women, children, and elderly, were massacred by U.S. Army soldiers in My Lai, Vietnam in March $1968 .^{78}$ The My Lai Massacre, as it became known, took place less than two months following the Tet Offensive, which had "further eroded support" for the American effort in Vietnam. ${ }^{79}$ Initially reported as a daylong battle in which over a hundred Communists were killed, ${ }^{80}$ a cover up would later be exposed and lead to dozens being charged for roles in either the cover up or the massacre itself. ${ }^{81}$ In the end, very few were actually tried and only one, Lieutenant William Calley, was convicted. ${ }^{82}$ A court-martial found Calley guilty of the premeditated murder of twenty-two infants, children, women, and old men, and of assault with

\footnotetext{
76 Administrative reprimands can lead to administrative separations, resulting in discharge characterizations of service of less than 'honorable,' which in turn may result in a forfeiture of some veteran's and other benefits normally afforded those with an 'honorable' discharge. See Major John W. Brooker et. al., Beyond "T.B.D.": Understanding VA's Evaluation of a Former Servicemember's Benefit Eligibility Following Involuntary or Punitive Discharge from the Armed Forces, 214 MIL. L. REV. 1, 24-41 (2012).

See R. CTS-Martial 601(a).

78 See William George Eckhardt, My Lai: An American Tragedy, 68 UMKC L. REV. 671,675 (2000).

79 See Tet Offensive, History.cOM, http://www.history.com/topics/tet-offensive (last visited June 30, 2013).

80 See Seth Robson, Clemency is last hope for a more normal life, STARS AND STRIPES (May 12, 2009), http://www.stripes.com/news/clemency-is-last-hope-for-a-more-normallife-1.91416 ("U.S. infantrymen had killed 128 Communists in a bloody day-long battle.").

${ }_{81}$ See My Lai: The Cover-up, BBC News (Mar. 13, 1998, 1:15 PM), http://news.bbc.co.uk/2/hi/asia-pacific/64640.stm.

S2 Eckhardt, supra note 78, at 678.
} 
intent to murder a child. ${ }^{83}$ After the longest court martial in history, Calley was dismissed from service and further sentenced him to life imprisonment and hard labor. ${ }^{84}$

The CA reviewing Calley's sentence reduced his life imprisonment to twenty years, and the Secretary of the Army further reduced his confinement to ten years of hard labor. ${ }^{85}$ Ultimately, Calley served a total of only three and a half years. He was released from confinement at Fort Leavenworth when a federal district judge in Georgia overturned his sentence, but he remained at Fort Benning, Georgia under house arrest following reinstatement of the conviction by the Fifth Circuit Court of Appeals. In 1975, the Secretary of the Army paroled Calley. ${ }^{86}$

Forty years later, the U.S. again found itself in a protracted, unpopular war. ${ }^{87}$ Today, however, advances in telecommunications and media technology not only enhance battlefield reporting, but also facilitate media reporting of a combat theater's activities in near-real time. As such, cover-ups like My Lai, though still possible, are rare today. So, it is of little surprise that much of the world knew, within hours of it occurring, about the massacre in Afghanistan of sixteen people, including women and children, perpetrated by an American soldier in early March 2012. ${ }^{88}$ Robert Bales, after seeing a peer lose a leg to an improvised explosive device in the days before and then consuming alcohol the night before, left his small Army outpost near Kandahar sometime before sunrise, walked to a nearby village, and killed multiple men, women, and children from several Afghan families. ${ }^{89}$

83 See United States v. Calley, 48 C.M.R. 19, 21 (1973).

84 See Archive Audio of Calley Trial, Foreign Affairs - 1971 Year in Review, UPI.COM, http://www.upi.com/Audio/Year_in_Review/Events-of-1971/CalleyTrial\%2C-Foreign-Affairs/12295509436546-8/ (last visited March 17, 2015).

85 See id.. Congress has only recently significantly diminished a CA's authority to modify the findings and/or sentence of a qualifying offense; see R. CTS-MARTIAL 1107(c); UCMJ art. 60, 10 U.S.C. § 860 (2012); NDAA FY14, Pub. L. No. 113-66, $\S 1702$ (2013); NDAA FY15, Pub. L. No. 113-291, § 531 (2014) (supporting proposition Congress has only recently significantly diminished a CA's authority to modify the findings and/or sentence of a qualifying offense).

86 See Major Jeffrey F. Addicott \& Major William A. Hudson, Jr., The Twenty-Fifth Anniversary of My Lai: A Time to Inculcate the Lessons, 139 MIL. L. REV. 153, 161 (1993).

87 See Elisabeth Bumiller \& Allison Kopicki, Support in U.S. for Afghan War Drops Sharply, Poll Finds, N.Y. Times (Mar. 26, 2012), http://www.nytimes.com/2012/03/27/ world/asia/support-for-afghan-war-falls-in-us-poll-finds.html?pagewanted=all\&_r=0.

88 See Jim Michaels \& Oren Dorell, Killings of civilians threaten Afghanistan mission, USATODAY.COM (Mar. 12, 2012, 8:30 AM), http://usatoday30.usatoday.com/news/ world/story/2012-03-11/afganistan-civilian-shootings/53472526/1.

89 See Adam Geller, Details emerge about US suspect in Afghan massacre, YAHOO! News (Mar. 16, 2012, 5:43 PM), http://news.yahoo.com/details-emerge-us-suspectafghan-massacre-071707145.html. 
According to Bales' civilian defense team, Bales had suffered combat injuries twice previously, including a traumatic brain injury, while on one of three prior deployments to Iraq, and likely suffered from post-traumatic stress disorder, or PTSD.$^{90}$ Because of injuries suffered in Iraq, Bales did not expect to be part of his unit's deployment to Afghanistan during the timeframe his crime was committed. ${ }^{91}$ Considering the totality of all these factors, it seemed unlikely that Bales would face the death penalty. As one unnamed official said, "[w]hen it all comes out, it will be a combination of stress, alcohol and domestic issues-he just snapped." 92 But the political fallout, internationally, was substantial, with Afghanistan's government officials demanding a curtailment of the U.S. military's operating procedures. ${ }^{93}$ And so just before Christmas in 2012, the Army announced their intent to seek the death penalty for Bales. ${ }^{94}$

Bales' well-known lead civilian defense attorney, John Henry Browne, made no qualms about what issues he would bring to light at a court-martial convened with the intent to impose a sentence of death on Bales. In an indirect reference to PTSD, alcohol, and drug use by U.S. soldiers, and the stresses of repeated deployments to combat zones, Browne indicated that the CA's decision was "totally irresponsible," and that the Army was "trying to deflect criticism by not taking responsibility [for the soldiers in general]." 95 As a civilian defense attorney, Browne employed a strategy, emphasizing broad media exposure, ${ }^{96}$ less favored by uniformed defense counsel because of an adherence to the unique

$90 \quad I d$.

91 See James Dao, U.S. Identifies Army Sergeant in Killing of 16 in Afghanistan, N.Y. TimEs (Mar. 16, 2012), http://www.nytimes.com/2012/03/17/world/asia/afghan-shootingsuspect-identified-as-army-staff-sgt-robert-bales.html ("The family was counting on [Sergeant Bales] not being redeployed ... [h]e and the family were told that his hours in the Middle East were over." (quoting Bales' attorney, John Henry Browne)).

92 Eric Schmitt \& William Yardley, Accused G.I. 'Snapped' Under Strain, Official Says, N.Y. TiMES (Mar. 15, 2012), http://www.nytimes.com/2012/03/16/world/asia/ suspect-in-afghan-attack-snapped-us-official-says.html.

See Askia Muhammad, Full fallout of Afghan massacre still unknown, THE FINAL CALL, http://www.finalcall.com/artman/publish/World_News_3/article_8697.shtml (last updated Mar. 27, 2012).

See Kim Murphy, Army seeks death for Sgt. Robert Bales in Afghan shooting rampage, LOS ANGELES TIMES, Dec. 19, 2012, http://articles.latimes.com/2012/ $\mathrm{dec} / 19 /$ nation/la-na-nn-robert-bales-court-martial-afghan-slaying-20121219.

95 Id.; see also Kirk Johnson, Guilty Plea by Sergeant in Killing of Civilians, N.Y. TimES, June 5, 2013, http://www.nytimes.com/2013/06/06/us/sergeant-robert-balestestimony.html.

96 Winston Ross, Robert Bales, Accused in Afghan Deaths, Hires Flashy Lawyer John Henry Browne, THE DAILY BEAST, Mar. 19, 2012, http://www.thedailybeast.com/ articles/2012/03/19/robert-bales-accused-in-afghan-deaths-hires-flashy-lawyer-johnhenry-brown.html. 
culture of the military. By permitting the media a glimpse into how broader issues might frame Bales' defense, Browne compelled the government to reconsider the political fallout, in a domestic light. On June 5, 2013, Robert Bales pled guilty to the murders in exchange for the government removing the possibility of the death penalty in the case. ${ }^{97}$ He was subsequently sentenced by a military panel to life without the possibility of parole. ${ }^{98}$

\section{Capital Referral Based on the Crime, or Not}

How does someone compare Calley's case to Bales' case with regards to why the military initially sought the death penalty in one case, but not the other? Someone might attempt to argue that one crime was more heinous than the other, but it suffices to say that both were horrendous crimes. Both occurred during wars that were, at the time, largely unpopular with the U.S. populace, though Vietnam was arguably the more unpopular of the two. And though the military generally considers itself insulated from politics, at least at nearly every level except the very highest, it appears to be precisely politics that drove the death sentence decisions. In Calley's case, American involvement in Vietnam was beginning to wind down, though not due to success, at the time of his trial. A number of politicians did not want to see American failures in Vietnam on further display at a time when plans for a facesaving exit could be easily undermined. ${ }^{99}$

Calley also differed from Bales' case in that many saw Calley as a scapegoat. While his conviction was for the premeditated murder of twenty-two men, women, and children, he was relatively junior in the chain of command of officers investigated in response to the massacre. ${ }^{100}$ And while it is difficult to fathom anything less than the most severe punishment available being directed for such a heinous crime, political sentiment had an impact in two ways. ${ }^{101}$ First, if only Calley was to be convicted, he should not be punished for the actions of all involved, particularly more senior officers. ${ }^{102}$ And second, prolonged exposure to the public of this tragedy was not in the country's interest. ${ }^{103}$

97 See Kirk Johnson, Guilty Plea by Sergeant in Killing of Civilians, N.Y. TimEs, June 5, 2013, http://www.nytimes.com/2013/06/06/us/sergeant-robert-bales-testimony.html.

Afghan massacre soldier Robert Bales gets life sentence, BBC News, Aug. 23, 2013, http://www.bbc.co.uk/news/world-us-canada-23820790.

99 See Eckhardt, supra note 78, at 684.

100 See id. at 683 n.48; Telford Taylor, Lieutenant Calley and the President, LifE, Apr. 16,1971 , at 40.

${ }_{101}$ See Eckhardt, supra note 78, at 684.

102 See Eckhardt, supra note 78, at 683 n.48; Telford Taylor, supra note 100, at 40.

103 See Eckhardt, supra note 78, at 682-83. 
Bales' actions were equally heinous, though the scale of his differed from that of Calley's. Further, Bales' actions were individual actions, not in conjunction with or part of the actions of others. So in Bales' case, there was no scapegoat claim. Bales was also a leader, a noncommissioned officer whose rank was commensurate with responsibility for an infantry squad or platoon. ${ }^{104}$ But Bales also would have answered to a platoon sergeant, platoon leader, company first sergeant, company commander, and so on. If Bales' immediate chain of command had competently policed the welfare of its soldiers, Bales and others would not have had access to the alcohol and drugs claimed by both the Army and Bales' defense team. ${ }^{105}$ Bales' extended chain of command, including the Army's most senior leaders, was responsible for ensuring Bales and all soldiers were both physically and mentally fit for war. Despite the military's cookie cutter, mass production, one-size-fits-all approach to training and deployment, every service member processes mental and physical trauma differently, particularly when multiple combat-related injuries acquired over multiple deployments are present. The initial decision to seek the death penalty for Bales was arguably a reaction to the political fallout and damage to military objectives in Afghanistan. ${ }^{106}$ But it was the potential for domestic fallout, by virtue of bringing to light, in a public trial, the military's ineffectiveness in dealing with treatment of service members exposed time and time again to the horrors of war, that very likely persuaded senior leaders to consider in a more pragmatic manner a punishment other than death for Bales.

Though Calley and Bales both intentionally murdered many civilian non-combatants, on the battlefield, neither was ultimately tried capitally. In still other military capital cases, also heinous and horrendous in their nature but arguably less so in that the victims numbered far less and included no children, the decisions to seek the death penalty appear to be tinged with bias, if not lacking, comparatively so, fairness and impartiality.

104 See U.S. ARMY FIEld MANual 3-21.8 (Mar. 28, 2007), available at http://armypubs.army.mil/doctrine/DR_pubs/dr_a/pdf/fm3_21x8.pdf.

105 See Barbara Starr, Lawyer: Special ops troops gave accused killer alcohol, steroids, CNN.COM (May 30, 2013 10:21 AM), http://www.cnn.com/2013/05/30/us/soldierafghan-killings-plea.

${ }_{106}$ See Matthew Schofield \& Nancy A. Youssef, Analysts fear Afghan massacre fallout: Soldier held in shootings could get death penalty, SOUTH BEND TRIBUNE (Mar. 13, 2012), http://articles.southbendtribune.com/2012-03-13/news/31162242_1_afghangovernment-afghan-civilians-afghan-lawmakers. 


\section{When the Victims are Service Members}

\section{Seeking Capital Punishment for Killing Our Own-In Peace}

Apparent bias underscores the perception of arbitrariness in the decision to seek the death penalty when the victims are also service members. The case of Ivette Davila was just such a crime. The double murder occurred in a civilian community outside Tacoma, Washington. Davila, a young Hispanic woman, brutally murdered an Army couple, believing the wife was romantically involved with Davila's former boyfriend, and then kidnapped the slain couple's six-month-old baby. She further tried to cover up the shooting by dousing the bodies in muriatic acid. ${ }^{107}$ Because the murders did not occur on a military installation, Davila was initially charged in Pierce County, Washington. But at the request of officials out of Fort Lewis, civilian authorities quickly ceded jurisdiction to the Army and Davila was charged with premeditated murder under the UCMJ. It was subsequently uncovered that when Davila was just nine-years-old, her mother's boyfriend sexually molested her. ${ }^{108}$ As a result, she manifested schizotypal personality disorder, a mental health condition in which a person has disturbances in thought patterns, appearance, and behavior as well as difficulty with relationships. ${ }^{109}$ Her background and disorder notwithstanding, the Army referred her case capitally, "empowering" a panel to sentence her to death. ${ }^{110}$

Davila would eventually plead guilty to avoid the death penalty and despite mitigation testimony at sentencing about her background and the personality disorder, she was give life without the possibility of parole. ${ }^{111}$ No one can question the heinous nature of Davila's actions. But one can question the factors considered by the $\mathrm{CA}$ in referring the case capitally. Some of the factors present, though not necessarily considered, in obtaining jurisdiction and initially seeking the death penalty include the following: the victims were soldiers, veterans of Iraq, and white; Davila

107 See Soldier charged with premeditated murder, KOMONEws.COM (Mar 6, 2008 3:19 PM), http://www.komonews.com/news/16353886.html.

108 See Luke Duecy, Army specialist sentenced to life in prison for double murder, KOMONews.COM (Aug. 24, 2010 6:23 PM), http://www.komonews.com/news/local/ 101436214.html.

109 Id; See Schizotypal Personality Disorder, A.D.A.M. Med. EnCyClopedia (Nov. 17, 2012), http://www.ncbi.nlm.nih.gov/pubmedhealth/PMH0002493/.

110 See Mike Barber \& Kathy Mulady, Soldier accused of killing couple handed to Army: Davila could face death if convicted in court-martial, SEATtLePI.com (Mar. 5, 2008 10:00 PM), http://www.seattlepi.com/local/article/Soldier-accused-of-killingcouple-handed-to-Army-1266332.php (detailing the background of Davila's case and referral to court-martial).

111 See Duecy, supra note 108. 
had not yet served in either Iraq or Afghanistan and thus could not claim war-related posttraumatic stress disorder, or PTSD; Davila is a female, but also a soldier and therefore should be treated no differently based upon gender; and, perhaps most prominent, the state of Washington has never executed a female. ${ }^{112}$ Though it is uncertain whether the death penalty in this case was used as leverage, it is certain that the Army agreed not to pursue the death penalty in exchange for Davila's guilty plea, ensuring that a young woman spends the remainder of her life under maximum security confinement for her horrible actions. ${ }^{113}$

\section{Seeking Capital Punishment for Killing our Own - In War}

As much as the perception of bias seems to weigh in capital punishment decisions when the victims are service members, it appears even more pronounced when victims were serving their country at war. In a so-called "fragging" incident, ${ }^{114}$ Alberto Martinez was accused of the premeditated murder of his company's commanding and executive officers, Phillip Esposito and Louis Allen, while deployed near Tikrit, Iraq in June 2005. The three were members of a New York Army National Guard unit mobilized for deployment to Iraq. Martinez, reported to be disgruntled with and making threats against his company commander, was accused of setting up and detonating a claymore mine and several grenades near Esposito's quarters, in which both he and Allen were located at the time. ${ }^{115}$ Initially thought to be victims of a rocket or mortar attack, the wounds sustained by Esposito and Allen indicated otherwise and led to the initial investigation. ${ }^{116}$

Following the conclusion of an Article 32 preliminary hearing, ${ }^{117}$ roughly equivalent to grand jury proceedings in the civilian judicial system, the investigating officer recommended that Martinez face a

\footnotetext{
112 See Christine Clarridge, Jealousy may have fueled killings of 2 fellow Fort Lewis soldiers, THE SeAtTle TiMES (Mar. 4, 2008 6:56 PM), http://seattletimes.com/ $\mathrm{html} /$ localnews $/ 2004258352$ coupleslain $04 \mathrm{~m} . \mathrm{html}$; Executions by State in the U.S. 16082002: The ESPY File Executions by State, Death Penalty Information Center, http://www.deathpenaltyinfo.org/documents/ESPYstate.pdf (last visited Apr. 11, 2015).

${ }_{113}$ See Rob Carson, Killer won't face execution, TheOlymPIAn.com (Aug. 24, 2010), http://www.theolympian.com/2010/08/24/1345171/killer-wont-face-execution.html.

${ }_{114}$ See Paul von Zielbauer, When a Soldier Attacks a Comrade, N.Y. TimES (June 16, 2008), http://www.nytimes.com/2008/06/16/nyregion/16guard.springer.html.

115 See Joseph Giordono, Hearing starts for soldier accused of fragging in Iraq, STARS AND STRIPES (Nov. 1, 2005), http://www.stripes.com/news/hearing-starts-for-soldieraccused-of-fragging-in-iraq-1.40440.

$116 \quad I d$.

117 See UCMJ art. 32, 10 U.S.C. § 832 (2012), amended NDAA FY 14, Pub. L. No. $113-66, \S 1702,127$ Stat. 672, 954-55 (2013).
} 
general court-martial for premeditated murder. ${ }^{118}$ The CA in the case, Army Lieutenant General John Vines, referred the case capitally. Before the case was brought to trial, however, Martinez offered, in writing, to plead guilty and accept a life sentence in prison to avoid a possible death sentence. ${ }^{119}$ The plea offer stipulated that Martinez would recite to a military judge the circumstances of the offenses to which he would plead guilty. ${ }^{120}$ Lieutenant General Vines promptly rejected Martinez's guilty plea offer. ${ }^{121}$ At the time, the only other publicly known case of an enlisted soldier charged with intentionally killing superiors during the Iraq war was that of Hasan Akbar. In 2003, Akbar, serving with the $101^{\text {st }}$ Airborne Division, killed two officers in Kuwait in a grenade and rifle attack. ${ }^{122}$ Two years later, Akbar was convicted at court-martial and sentenced to death. ${ }^{123}$ Coincidentally, Lieutenant General Vines had a hand in that case as well, affirming Akbar's death sentence in $2006 .{ }^{124}$

Martinez's court-martial was conducted at Fort Bragg, North Carolina in October 2008. ${ }^{125}$ And despite circumstantial evidence that many considered sufficient for conviction, Martinez was acquitted after a panel deliberated for two days. ${ }^{126}$ Vines demonstrated ardent support for the death penalty, ${ }^{127}$ not only in his affirmation of Akbar's death sentence but in his rejection of Martinez's plea offer as well. According to Gary Solis, a retired Marine Corps judge and current law professor at Georgetown University Law Center, "the only reason you should turn [that offer] down is if you have an absolutely bulletproof case." ${ }^{128}$ Again, it is impossible to know exactly all of the factors considered in refusing a plea offer in favor of pursuing the death penalty for Martinez, but the circumstances would seem to indicate an element of subjectivity entered into the process.

118 See Investigating Officer Recommends General Court-Martial, AM. FORCES PRESS SERV. (Nov. 1, 2005), http://www.defense.gov/news/newsarticle.aspx?id=18413.

119 See Plea Offer at 1, United States v. Alberto B. Martinez (2006), http://graphics8.nytimes.com/packages/pdf/20090220_MARTINEZ.pdf.

${ }_{120}$ See Paul von Zielbauer, After Guilty Plea Offer, G.I. Cleared of Iraq Deaths, N.Y. Times (Feb. 20, 2009), http://www.nytimes.com/2009/02/21/nyregion/21 frag.html.

121 Id.

122 Id.

123 Id.

$124 \mathrm{Id}$.

125 von Zielbauer, supra note 120

126 See David Zucchino, Widows pursue justice in soldiers' slayings, Los ANGELES Times (Apr. 8, 2010), http://articles.latimes.com/2010/apr/08/nation/la-na-fraggingwidows9-2010apr09; von Zielbauer, supra note 120.

127 See Schmidle, supra note 2, at 64.

128 See von Zielbauer, supra note 120. 


\section{Abuse of THE Dual Sovereignty Doctrine}

Those subject to the UCMJ include anyone in the military. As broad as that may seem, it is actually even still broader than most civilians, and many subject to the UCMJ, realize. In addition to those serving on active duty, military reservists are subject to the UCMJ while on inactive duty, as well as "civilians" who receive retirement compensation as a result of retiring from active duty. ${ }^{129}$ In some instances, even certain civilians who have never served on active duty (i.e. regular active duty, reservists on active duty for training, etc.) are subject to the broad reach of the UCMJ. ${ }^{130}$ Thus, whether someone is, or is not, subject to the authority of the UCMJ is fairly straightforward. ${ }^{131}$ But determining the factors that go into deciding whether the military will assert its jurisdictional authority is anything but straightforward. For example, Ivette Davila's crimes, crimes not specific to the role of the military, occurred within the jurisdiction of Pierce County (Tacoma), Washington, ${ }^{132}$ yet the military assumed jurisdiction over her case. Though obviously not stated explicitly by military authorities, the fact that Washington has never executed a female could be perceived to be a factor. ${ }^{133}$

The military's broad authority and discretion is not limited to just usurping jurisdiction for sake of being the jurisdiction of first instance. In fact, the military may, through its manipulation of the dual sovereignty doctrine, try a service member by court-martial following a state's criminal proceedings against that service member, whether or not the state secured a conviction, failed to secure a conviction, or even acquitted the service member.

\section{A. When Can, and Should, the Military Exercise Jurisdiction?}

Some experts criticize the military's routine practice of prosecuting service members for crimes that would not otherwise be subject to the UCMJ. The Framers of the Constitution were against the idea. ${ }^{134}$ According to David Glazier, a former U.S. Naval surface warfare officer and current Professor of Law at Loyola Law School, "the Articles of War, which were adopted during the Revolution and continued for half our history, said that when a soldier committed an offense against the local civilian population, it was an offense for the commanding officer to

See UCMJ art. 2(a), 10 U.S.C. $\S 802$ (a) (2012).

See id. $\S 802(a)(10)$.

See id. $\S 802$.

See Soldier Charged With Premeditated Murder, supra note 107.

See Death Penalty Information Center, supra note 112, at 395-98.

See Schmidle, supra note 2, at 64. 
fail to turn over a soldier to the civilian authorities." ${ }^{135}$ But after the U.S. invasion of Mexico in 1846, according to Glazier, "General Winfield Scott expanded the military's jurisdiction over its soldiers into the civilian world, in order to hold them accountable for alleged crimes in Mexican towns and villages." 136 That policy lasted more than a hundred years until, according to Fred Morrison, the U.S. Supreme Court held that "[e]very extension of military jurisdiction is an encroachment on the jurisdiction of the civil courts, and, more important, acts as a deprivation of the right to jury trial and of other treasured constitutional protections." 137

\section{The Competing Views of $O^{\prime}$ Callahan and Solorio}

In O'Callahan v. Parker, the Court went from constraining the continuing expansion of the military's jurisdiction to limiting it to only those crimes with a direct nexus to the military. O'Callahan held that the military could only exercise jurisdiction over those crimes, which are "service-connected." 138 By not defining "service-connected," however, $O$ 'Callahan impacted the military's ability to exercise jurisdiction in a straightforward manner. And so, nearly twenty years later, the U.S. Supreme Court, under the new leadership of Chief Justice William Rehnquist, disregarded stare decisis, overruled $O$ 'Callahan in a six-tothree decision, and greatly expanded the reach of the UCMJ by restoring the military's authority to prosecute a significantly wider range of crimes committed by service members. ${ }^{139}$ Solorio v. United States held that the military may exercise jurisdiction over any crime, whether specific to the military or not, committed by a member of the Armed Forces. ${ }^{140}$ The more substantial implications of Solorio were the greater possibility of a service member facing charges for the same crime in different sovereigns and the need for greater cooperation between local civilian and military law enforcement and legal officials.

\footnotetext{
135 Id.

136 Id.; see also Hamdan v. Rumsfeld, 548 U.S. 557, 590 (2006) (discussing General Scott's use of commissions to fill a jurisdictional void).

137 See Fred K. Morrison, Court-Martial Jurisdiction: The Effect of O'Callahan v. Parker, 11 WM. \& MARY L. REV. 508, 508 (1969).

138 See O'Callahan v. Parker, 395 U.S. 258, 272 (1969) ("[T]he crime to be under military jurisdiction must be service connected ....”), overruled by Solorio v. United States, 483 U.S. 435 (1987); see also Morrison, supra note 137, at 508.

139 See generally Solorio, 483 U.S. 435.

140 See id.
} 


\section{O'Callahan Overruled by Solorio-Actual Implications}

A recent example of Solorio's implications, by way of a non-capital case, was that of Pentagon-assigned U.S. Air Force Lieutenant Colonel Jeffrey Krusinski. Originally charged with sexual battery in Arlington County, Virginia, Krusinski was also at risk of facing a general courtmartial following adjudication of civilian criminal proceedings. The Air Force requested jurisdiction in the case, but Arlington County prosecutors declined. ${ }^{141}$ Regardless of how the case could have been disposed of in Arlington County, ${ }^{142}$ trial by court-martial could still have been pursued by the Secretary of the Air Force if, according to an unnamed military lawyer, the Secretary determined that Krusinski's civilian criminal prosecution "fail[ed] to meet the ends of good order and discipline." $" 143$

Such intentionally equivocal and ambiguous language does not necessarily equate to conviction in the civilian criminal proceedings. Actual policy, however, is that "a person subject to the UCMJ who has been tried in a civilian court may, but ordinarily will not be tried by court-martial or punished under UCMJ for the same act over which the civilian court has exercised jurisdiction." ${ }^{144}$ This is the stated Army policy but is consistent with the other services. ${ }^{145}$ Thus, the actual implication of Solorio, stated policy, and evolving practice and experience is that the military is free to pursue prosecution of any crime it so desires, whether already adjudicated in civilian criminal proceedings or not, so long as the accused is a service member.

\section{B. When the State Secures a Conviction}

Though guilty of terrible crimes, Ronald Gray's case is another example of Solorio's actual implications. In 1987, just months after the U.S. Supreme Court decided Solorio, Gray pled guilty to multiple violent

141 See Jeff Schogol, Prosecutor will not transfer sexual assault prevention chief's case to Air Force, AiRForCETIMES.COM (May. 8, 2013 4:57 PM), http://www.airforcetimes. com/article/20130508/NEWS/305080023/Prosecutor-will-not-transfer-sexual-assaultprevention-chief-s-case-Air-Force.

142 See Rachel Weiner and Matt Zapotosky, Air Force colonel acquitted in assault trial, WASHIngton Post (Nov. 13, 2013), http://www.washingtonpost.com/local/crime/jeffreykrusinski-air-force-colonel-accused-of-assault-goes-on-trial-in-

arlington/2013/11/13/04aa0dfa-4c9f-11e3-ac54-aa84301ced81_story.html.

143 See Nancy Montgomery, Who has jurisdiction in sex assault aase: Civilian or military court?, STARS AND STRIPES (May 8, 2013), http://www.stripes.com/news/whohas-jurisdiction-in-sex-assault-case-civilian-or-military-court-1.220048.

144 See U.S. ARMY Regulation 27-10, para. 4-2 (Oct. 3, 2011).

145 See James P. Pottorff, Jr., Solorio v. United States: The Supreme Court Reverses Direction on Jurisdiction over Military Offenders in Civilian Communities, 57-OcT J. KAN. B. Ass'N, 29, 33 (1988). 
crimes, including two murders and five counts of rape, and was sentenced to three consecutive and five concurrent life terms by the Cumberland County, North Carolina Superior Court. ${ }^{146}$ Following his plea and sentencing in Cumberland County's Superior Court, military authorities then also charged him with multiple violent crimes, including premeditated murder of the same two victims for which North Carolina has just sentenced him to multiple life terms. Less than six months following sentencing by the state, Gray was convicted at a general courtmartial and sentenced to death. ${ }^{147}$ Unquestionably, Gray's crimes were especially heinous. And North Carolina, in meting out justice both efficiently and expeditiously, saw to it that Gray would remain confined for the remainder of his natural life. Unsatisfied with those results, however, the military sought instead to take Gray's life just as he had taken the lives of his victims. There can be no dispute as to why the military exercised its jurisdiction, even after adjudication of the case in civilian criminal court. The Army felt that the civilian prosecution and sentence of multiple life terms "failed to meet the ends of good order and discipline." $" 148$

\section{When the State Fails to Secure a Conviction}

A more recent case in which the military initially permitted the state to retain jurisdiction of a service member in a murder trial was that of Brent Burke. Burke, accused of the 2007 premeditated murders of his estranged wife and her former mother-in-law, faced trial by general court-martial in May 2012 at Fort Campbell, Kentucky. ${ }^{149}$ Despite referral of premeditated murder charges, the CA did not refer Burke's case capitally as evidenced by his panel numbering less than twelve. ${ }^{150}$

When premeditated murder charges are referred, one naturally ponders why not capitally? In this particular instance, Burke's courtmartial for the two murders was his fifth trial. ${ }^{151}$ After four trials in Hardin County, Kentucky, in which two ended with hung juries and two others in mistrials, a judge dismissed the charges in June 2011 when

\footnotetext{
146 See United States v. Gray, 37 M.J. 730, 733 (A.C.M.R. 1992).

147 Id.

148 Montgomery, supra note 143.

149 See Joey Brown \& Charles Gazaway, Verdict could be near in Brent Burke court martial, WAVE3 News, (May 7, 2012 11:58 PM) http://www.wave3.com/story/ 18184922/military-panel-reaches-finding-in-court-martial-of-double-murder-suspectbrent-burke.

150 Id.

151 See id.
} 
prosecutors concluded they would not be able to secure a conviction. ${ }^{152}$ Burke's Army enlistment should have ended while he was in custody pending the multiple state trials, but he was retained on active duty pending adjudication of the state charges so that he could be properly processed out of the Army. ${ }^{153}$ But less than two weeks after being released from state custody for return to Fort Campbell for separation processing, Army officials charged Burke under the UCMJ for the murders. ${ }^{154}$

Despite the Army electing to have Burke face a fifth trial for the murders, one Army expert actually claimed that "a military court martial would grant more rights than a civilian trial would." In a court-martial, according to the military criminal law instructor at The Judge Advocate General's Legal Center and School, "good soldier" evidence may be presented. ${ }^{155}$ For example, "[the accused] can come in and talk about how good of a soldier [he has] been, and [the panel] may find, because this soldier is of such a high caliber, [they] do not believe he is capable of committing this type of offense and find him not guilty." ${ }^{156}$ Following his trial heard by a panel numbering just seven, Burke was found guilty after less than three hours of deliberations. But because the case was not referred capitally, Burke instead was sentenced to only life in prison without parole. ${ }^{157}$

Though Burke's trial was not a capital case, he was convicted of offenses that could have been referred capitally. Only the CA knows for certain why the case was not referred capitally. That the CA decided to force Burke to stand trial a fifth time seems, at the very least, unfair and partial. But the dual sovereignty doctrine permits successive prosecutions, regardless of the outcome in the initial jurisdiction as evidenced in Gray. ${ }^{158}$ Despite contentions by some legal scholars that

152 See Claudia Coffey \& Mike Colombo, Charges dismissed against former Fort Campbell soldier Brent Burke: released into US Military custody, WHAS11.COM (June 29, 2011 5:32 PM), http://www.whas11.com/story/news/ crime/2014/10/10/15490808/.

153 Id.

154 See Army charges Fort Campbell soldier in 2 deaths, Associated Press (July 10, 2011), http://news.yahoo.com/army-charges-fort-campbell-soldier-2-deaths-042937392. html.

${ }_{155}$ See Marcelena Spencer, Honor and Dishonor, CBS NEws (Feb. 16, 2013 11:01 PM), http://www.cbsnews.com/8301-18559_162-57569724/honor-and-dishonor-thetrials-of-sgt-brent-burke/.

$156 I d$; see also NDAA FY 15, Pub. L. No. 113-291, §536 (2014) (eliminating admissibility of the "good soldier" defense for many offenses, but not murder).

157 See Brown \& Gazaway, supra note 149; see also Steve Teller, Brent Burke sentenced to life without parole. WLKY NEws, May 9, 2012, available at http://www.wlky.com/news/local-news/kentucky-news/Brent-Burke-sentenced-to-lifewithout-parole/12831286.

158 See United States v. Lanza, 260 U.S. 377, 382 (1922). 
such actions violate "the spirit of the Constitution's prohibition on double jeopardy," 159 the military will continue, absent significant changes to policy or statute, to assert jurisdiction when it arbitrarily determines that civilian prosecutions, whether successful or not, "fail to meet the ends of good order and discipline." 160

\section{When the Service Member is Acquitted by the State}

And what of Timothy Hennis, following his acquittal in the state's second murder trial after previously sending him to North Carolina's death row only a few years earlier? Hennis reenlisted in the Army in 1989, served in both the first Gulf War and in Somalia during the period of the infamous "Black Hawk Down"161 incident, was considered an outstanding soldier by colleagues, and was also later involved in his son's scouting activities as a scoutmaster. ${ }^{162}$ Hennis was honorably retired from the Army in 2004 after a twenty-three-year military career. ${ }^{163}$ Not long after Hennis retired in Washington state, cold case detectives in North Carolina were reexamining the Eastburn murders. DNA technology had advanced significantly since the trials of Hennis, and the two sperm samples taken from Katie Eastburn's body had been kept by the Cumberland County sheriff's department for nearly twenty years. ${ }^{164}$ It turned out the samples were sufficient for a DNA test, and the North Carolina crime lab produced a match-Timothy Hennis. ${ }^{165}$

But Hennis had already faced trial, twice, and been acquitted. And the Double Jeopardy Clause of the Fifth Amendment says that no person shall "be subject for the same offense to be twice put in jeopardy of life." 166 Because the Cumberland County detectives knew that Hennis could not be tried again by North Carolina, the detectives decided to meet with military prosecutors at Fort Bragg and present them with the DNA evidence. The military prosecutors, in turn, asked the CA to consider charging Hennis with the murders under the UCMJ, and the CA did not deliberate long in his decision. ${ }^{167}$ Lieutenant General John Vines, no stranger to seeking the death penalty for accused soldiers'

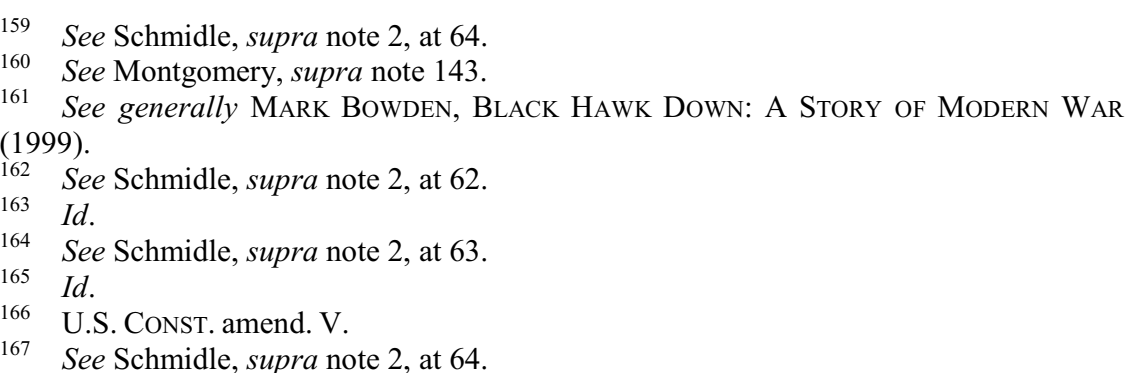


punishment, ${ }^{168}$ asked the Secretary of the Army to recall Hennis so that he could be tried, a third time, for the Eastburn murders. In September 2006, a little more than two years after he retired from the military, Hennis received orders from the Army recalling him out of retirement and back to active duty to face court-martial, and possibly death, for the murders of which he was acquitted nearly two decades earlier. ${ }^{169}$

Unlike most triple-murder suspects, Hennis was neither confined nor restricted prior to trial but instead given a desk job performing administrative duties while assisting in preparation for his defense. ${ }^{170}$ According to Colonel Michael Mulligan of the Army's Legal Services Agency, the decision to have Hennis tried again, where the state failed to secure a conviction, was not made lightly and the Hennis case was unique. ${ }^{171}$ The multiple Burke trials, however, would seem to indicate otherwise. $^{172}$

On April 8, 2010, the court-martial panel, after deliberating three hours, unanimously found Hennis guilty of the murders, paving the way for deliberations on the death sentence. ${ }^{173} \mathrm{~A}$ week later, the same panel again reached a unanimous verdict: Hennis was to be dishonorably discharged from the service and put to death. ${ }^{174}$ Hennis now waits out the appellate process sitting on death row at the USDB at Fort Leavenworth. When asked about the possibility of a successful appeal in an attempt to avoid death, Gary Eastburn, husband of Katie Eastburn at the time of her death, indicated he had no desire to see Hennis executed, but rather imprisoned for life without parole. ${ }^{175}$

\section{EliminATION OF Military JURISDICTION OVER CAPITAL OFFENSES}

\section{A. Rationale for Jurisdiction Over Capital Crimes Obsolete}

The purpose of our military is to defend the nation. And according to former Secretary of Defense Robert Gates, that now includes tasks such as "reviving public services, rebuilding infrastructure, and promoting

\footnotetext{
See von Zielbauer, supra note 120.

See Schmidle, supra note 2, at 64.

See id.

See id. at 65.

See Brown \& Gazaway, supra note 149.

See Schmidle, supra note 2, at 66.

See id. at 67.

Id.
} 
good governance." ${ }^{176}$ Such statements indicate just how far our military, as well as civilian society, has advanced since the early days of our nation. While the purpose of military justice has not changed, the service members on the receiving end of that justice and a modern, civilian criminal justice system tasked with addressing a wide range of unique, complex, and serious offenses has changed. Ad hoc, non-standing military tribunals like courts-martial are simply unnecessary to dispose of serious crimes in today's all-volunteer, professional force. Early military legal codes from which the UCMJ evolved were designed to enforce strict discipline within ranks that included mercenaries and sometimes even barbarous fighting forces. ${ }^{177}$

Early American military law, traditionally stricter and more sweeping than civilian law, did not automatically apply the Bill of Rights to service members. ${ }^{178}$ Today, however, advancements in global communications and transportation technology permit a better alternative, in a standing, fixed, and more experienced civilian criminal justice system, to adjudicate serious offenses committed by service members. And more importantly, it is critically imperative that service members are afforded no less Constitutional protection than civilians as a result of volunteering to serve their country, especially when death is the punishment sought. ${ }^{199}$

\section{B. Article III and State Courts More Than Capable}

Those questioning whether capital and other serious offenses otherwise subject to the UCMJ can be adequately addressed by civilian justice systems do so ill-informed. The standing Article III and state courts are more experienced than the courts-martial that are convened as individual circumstances require. Further, there is nothing unusual about capital offenses not uniquely military, except that the accused is likely a service member and deserving of all constitutional protections afforded anyone standing trial in an American civilian justice system.

What would a capital case, in which the accused was subject to the UCMJ, tried by the civilian justice system look like? In 1995, Louis Jones, Jr. was convicted and sentenced to death for the kidnapping and murder of a nineteen-year-old soldier, Tracie McBride, earlier that year after abducting her from Goodfellow Air Force Base near San Angelo,

176 David S. Cloud, Gates Says Military Faces More Unconventional Wars, N.Y. TIMES (Oct. 11, 2007), http://www.nytimes.com/2007/10/11/washington/11 gates.html?_r=0.

177 See Randy James, A Brief History of The Court-Martial, TIME (Nov. 18, 2009), http://www.time.com/time/nation/article/0,8599,1940201,00.html.

178 See id.

179 See Loving v. United States, 517 U.S. 748, 774 (1996) (Stevens, J., concurring). 
Texas. ${ }^{180}$ Jones was a retired Army Master Sergeant who had served in both Grenada and the Gulf War prior to his retirement just two years earlier, ${ }^{181}$ and as a member of the retired reserve receiving retirement compensation, Jones was subject to the UCMJ. ${ }^{182}$ However, despite being subject to the military's jurisdiction, Jones was instead prosecuted federally, presumably because he was no longer on active duty. Though the military did not exercise jurisdiction in his case, it nonetheless reinforces the argument that just because the military can exercise jurisdiction due to the accused being subject to the UCMJ, the offense occurring on a military installation, or even the victim being a service member, it does not mean that justice cannot be adequately or better served in the civilian justice system. ${ }^{183}$

\section{Jurisdictional Manipulation Unfair to Service Members}

The case of Timothy Hennis, as well as others discussed in this paper, indicates strongly the perception of intentional and adverse manipulation by the military justice system of the dual sovereignty doctrine, established in United States v. Lanza. ${ }^{184}$ Several constitutional and military law scholars have commented on the intent of the Framers and the impact of the military's manipulation of dual sovereign prosecutions. Army Lieutenant Colonel Charles Pritchard, a military attorney, advocated for the military to change its practice of successive prosecutions. Pritchard wrote that:

"[t]he military has engaged in dual sovereign prosecutions many times. Eighteen published cases alone show the military's willingness to invoke the dual sovereignty doctrine. The Framers of the Constitution did not intend a dual sovereignty doctrine to undermine the fundamental protection against double jeopardy. The Supreme Court erred to the significant detriment of generations of Americans when it created the doctrine based on faulty reasoning and no precedent, and it

\footnotetext{
180 See generally United States v. Jones, 132 F.3d 232, 237-39 (5th Cir. 1998).

181 Louis Jones Jr. - Executed March 19, 2002, The CANADian CoAlition Against THE DeAth PenAlty, http://archive.today/xjMfu (last visited March 18, 2015).

182 See UCMJ art. 2(a)(4), 10 U.S.C. § 802(a)(4) (2012).

183 See also Gabrielle Levy, Army base shooting suspect ID'd, UPI.com (June 11, 2013 4:12 PM), http://www.upi.com/Top_News/US/Blog/2013/06/11/Army-base-shootingsuspect-IDd/3501370981444/.

184 See United States v. Lanza, 260 U.S. 377 (1922) (. An act which was made an offense both by the state prohibition law and by the National Prohibition Act is an offense against each sovereignty, and may be punished by each without violating the Fifth Amendment prohibition on double jeopardy.).
} 
continued that error as it entrenched the doctrine in American jurisprudence. While the federal government and a majority of states have significantly limited the doctrine, the military has taken advantage of it." ${ }^{, 185}$

Law professor David Glazier, discussing Hennis, indicated issues of significant concern in the Hennis court-martial. Glazier explained:

" $[t]$ he Framers clearly intended that the military would not have authority to try soldiers for civilian offenses .....Even if it is true that it does not violate our current understanding of double jeopardy, it certainly violates the understanding of the Framers. And that is legally dubious.... Why does someone who dedicates their life to defending this country have fewer rights for a non-military offense as compared to a run-of-the-mill civilian? The fact that [Hennis] has completed his service and been recalled seems morally reprehensible." 186

The Framers did not intend for any individual to be tried successively by any sovereign. During the drafting of the Bill of Rights, a House proposal by James Madison regarding double jeopardy was rejected due to specifics of the language. ${ }^{187}$ The rejection of the Madison proposal and other formulations, however, seemed to indicate support for the Double Jeopardy Clause being made applicable to the federal government and states alike. ${ }^{188}$ In the Senate, the little floor debate that did occur over the meaning of the Clause indicates that it incorporated British common law, understood to bar successive prosecutions by different sovereigns. ${ }^{189}$ Thus, it is presumed that the prohibition on double jeopardy was to protect individuals from again being subjected to prosecution for the same offense, regardless of the prosecuting authority. ${ }^{190}$

While eliminating the military's practice of successive prosecutions would address manipulation of the dual sovereignty doctrine going forward, it still would not address those circumstances where the military

185 See Pritchard, Jr., supra note 18, at 2.

186 See Schmidle, supra note 2, at 65.

187 See Ronald Jay Allen, Bard Ferrall, and John Ratnaswamy, The Double Jeopardy Clause, Constitutional Interpretation and the Limits of Formal Logic, 26 VAL. U. L. REV. 281, 302 (1991).

${ }_{188}$ Id.

189 Id. at 303

190 Id. 
elects to exercise its jurisdiction if a state trial is not resolved by either conviction or acquittal. ${ }^{191}$ That the military could still subject a service member to trial by court-martial for a capital offense after a state failed, even in multiple prosecution attempts, to achieve a conviction further supports the argument that jurisdiction over service members accused of capital offenses should remain with the jurisdiction in which the offense occurred, be it state or federal. This will not only ensure that the rights of the military accused are neither manipulated nor eroded, but will also eliminate the perception that the military justice system fails to function fairly and impartially.

\section{CONCLUSION}

Our military has not always possessed the authority to execute its own, outside of wartime. And it was for good reason that the Second Continental Congress imposed that restriction. ${ }^{192}$ As our nation matured and its standards of decency evolved, however, Congress lifted those restrictions. ${ }^{193}$ But if a sentence must be the ultimate punishment, it should be so for nothing less than the most heinous and horrendous crimes. The taking of life should be neither for the maintenance of good order and discipline, particularly by a contemporary, professional armed force, nor especially for any individual bias.

The past quarter century has seen our military shrink, grow, and now shrink again. This accordion effect places a tremendous reliance, and burden, on our forces, both active and reserve. In turn, this more specialized and better trained force further blurs the distinction between the professional and citizen soldier, and greatly reduces the need for a military justice system to exercise its jurisdiction over capital or even serious offenses. This increasingly buttresses the argument that the gap between the protections afforded service members by the military and by civilian justice systems must be eliminated. ${ }^{194}$

The perception that when the death penalty is sought for capital crimes, it is more often sought when the victims are service members, is unspoken but prevailing. Abraham Lincoln said "[b]lood can not restore blood, and government should not act for revenge."195 The Civil War President hated executions and followed commanders' execution

\footnotetext{
191 See Brown \& Gazaway, supra note 148.

192 See United States v. Loving, 517 U.S. 748, $752-54$ (1996).

193 See UCMJ art. 118, 10 U.S.C. § 918 (2006).

194 See Andrew M. Ferris, Military Justice: Removing the Probability of Unfairness, 63

U. CIN. L. REV. 439, 485 (1994).

195 See Bessler, supra note 12, at 277.
} 
recommendations only reluctantly. ${ }^{196}$ When the military does seek the death penalty, it often does so in a manner appearing void of complete transparency and thus appears arbitrary. The repeated pursuit of dual sovereign prosecutions, and the resulting indirect erosion of the very constitutional protections that accused service members volunteered to protect, only casts further doubt on the capacity of the military to exercise jurisdiction in capital cases in a fair and impartial manner. The application of military justice by such process reinforces the concerns evidenced by the Second Continental Congress and, more recently, by the Warren Court's $O^{\prime}$ Callahan decision. ${ }^{197}$

The Court in $O^{\prime}$ 'Callahan, with its "service connection" holding, expressed a valid lack of confidence in the ability of the military justice system to adjudicate criminal matters fairly and impartially. ${ }^{198}$ And though Solorio returned to the military the jurisdiction it desired, jurisdiction over all crimes committed by service members because they are service members, critics nonetheless maintain the argument that the military justice system must be changed to ensure that service members' constitutional rights are not eroded by virtue of their being service members. ${ }^{199}$

The military has not had an execution in over fifty years. And as a 2011 New York Times editorial noted, "the de facto moratorium has not made the country or the military less secure." 200 In all that time, moreover, there has been no demonstrable evidence of directly-related failings in the maintenance of good order and discipline of the armed services. Any argument for authority by the military to retain jurisdiction over capital offenses is simply unjustifiable.

\footnotetext{
196 See John D. Bessler, The Birth of American Law 351 (2014).

197 See O'Callahan v. Parker, 395 U.S. 258, 272 (1969) (holding that for the military to exercise personal jurisdiction, the accused must be subject to the UCMJ, and a connection must exist between the accused's military duties and the alleged offense), overruled by Solorio v. United States, 483 U.S. 435 (1987).

198 See Ferris, supra note 194, at 458.

199 See id. at 459.

200 Editorial, The Military and the Death Penalty: Evidence of racial bias is further proof that it's time to abolish capital punishment, N.Y. TIMES, Sept. 1, 2011, at A28.
} 